\title{
Correlation of different cellular assays to analyze $T$ cell-related cytokine profiles in vitamin D-3- supplemented patients with multiple sclerosis
}

Citation for published version (APA):

Rolf, L., Smolders, J., van den Ouweland, J., Hupperts, R., \& Damoiseaux, J. (2019). Correlation of different cellular assays to analyze T cell-related cytokine profiles in vitamin D-3-supplemented patients with multiple sclerosis. Molecular Immunology, 105, 198-204.

https://doi.org/10.1016/j.molimm.2018.12.001

Document status and date:

Published: 01/01/2019

DOI:

10.1016/j.molimm.2018.12.001

Document Version:

Publisher's PDF, also known as Version of record

\section{Document license:}

Taverne

Please check the document version of this publication:

- A submitted manuscript is the version of the article upon submission and before peer-review. There can be important differences between the submitted version and the official published version of record.

People interested in the research are advised to contact the author for the final version of the publication, or visit the DOI to the publisher's website.

- The final author version and the galley proof are versions of the publication after peer review.

- The final published version features the final layout of the paper including the volume, issue and page numbers.

Link to publication

\footnotetext{
General rights rights.

- You may freely distribute the URL identifying the publication in the public portal. please follow below link for the End User Agreement:

www.umlib.nl/taverne-license

Take down policy

If you believe that this document breaches copyright please contact us at:

repository@maastrichtuniversity.nl

providing details and we will investigate your claim.
}

Copyright and moral rights for the publications made accessible in the public portal are retained by the authors and/or other copyright owners and it is a condition of accessing publications that users recognise and abide by the legal requirements associated with these

- Users may download and print one copy of any publication from the public portal for the purpose of private study or research.

- You may not further distribute the material or use it for any profit-making activity or commercial gain

If the publication is distributed under the terms of Article $25 \mathrm{fa}$ of the Dutch Copyright Act, indicated by the "Taverne" license above, 


\title{
Correlation of different cellular assays to analyze T cell-related cytokine profiles in vitamin $\mathrm{D}_{3}$-supplemented patients with multiple sclerosis
}

\author{
Linda Rolf ${ }^{\mathrm{a}, \mathrm{b}}$, Joost Smolders ${ }^{\mathrm{a}, \mathrm{c}}$, Jody van den Ouweland ${ }^{\mathrm{d}}$, Raymond Hupperts ${ }^{\mathrm{b}}$, \\ Jan Damoiseaux ${ }^{\mathrm{e}, *}$ \\ a Academic MS Center Limburg, Zuyderland Medical Center, Sittard, the Netherlands \\ ${ }^{\mathrm{b}}$ School for Mental Health and Neuroscience, Maastricht University Medical Center, Maastricht, the Netherlands \\ ${ }^{\mathrm{c}}$ Department of Neurology, Canisius Wilhelmina Hospital, Nijmegen, the Netherlands \\ ${ }^{\mathrm{d}}$ Laboratory for Clinical Chemistry, Canisius Wilhelmina Hospital, Nijmegen, the Netherlands \\ ${ }^{\mathrm{e}}$ Central Diagnostic Laboratory, Maastricht University Medical Center, Maastricht, the Netherlands
}

A R T I C L E I N F O

\section{Keywords:}

Cytokines

Intracellular

Flowcytometry

Supernatants

Multiple sclerosis

Vitamin D

\begin{abstract}
A B S T R A C T
Different laboratory approaches have been exploited to analyze an effect of vitamin $\mathrm{D}_{3}$ supplements on $\mathrm{T}$ cell cytokine profiles in multiple sclerosis, with poorly reproducible results. We assessed the correlation between intra-cellular flowcytometry analysis of CD4 $\mathrm{T}$ cell-enriched $\mathrm{CD} 3^{+} \mathrm{CD}{ }^{-}$lymphocytes after PMA/ionomycin stimulation directly ex-vivo or after $72 \mathrm{~h}$ pre-stimulation with anti-CD3, and cytokine levels excreted in culture supernatants. Pre-stimulation with anti-CD3 resulted in higher proportions of cells positive for IFN- $\gamma$, IL-17 A, IL4, IL-10 and GM-CSF (all P < 0.001), but not TNF- $\alpha$. Positive correlation between approaches was highly variable, but most eminent for IFN- $\gamma$ and IL-4 $(\mathrm{R}=0.608-0.612$ and $\mathrm{R}=0.677-0.777$, resp., all $\mathrm{P}<0.001)$. No effect of 16-weeks vitamin $\mathrm{D}_{3}$ supplements on any outcome was found except for a decreased TNF- $\alpha$ concentration in culture supernatants. Choice of immune-assay is, apparently, a relevant confounder for the reproducibility of individual studies.
\end{abstract}

\section{Introduction}

Cytokines are major effector molecules of $\mathrm{CD}^{+} \mathrm{T}$ cells, which can drive or suppress inflammatory conditions dependent on concentration and context. Concentrations of cytokines present in plasma or culture supernatants can be quantified by enzyme-linked immune-sorbent assays (ELISA) or addressable laser bead immune assays (ALBIA), while cellular proportions producing the respective cytokines can be quantified by intra-cellular flowcytometry (iFACS) or Elispot assays (Carter and Swain, 1997). These approaches reveal different characteristics of cytokines and can be used in complementary ways (Beebe and Orr, 2017). However, most often researchers chose the assay which fits their laboratory workflow best and this may introduce misinterpretation when comparing results across different methods.

In multiple sclerosis (MS) research, $\mathrm{T}$ cell-related cytokines have been assessed as biomarkers of inflammatory disease activity (Becher et al., 2017). Vitamin $\mathrm{D}_{3}$ (cholecalciferol) is the precursor of a potent immunomodulatory molecule $\left(1,25(\mathrm{OH})_{2} \mathrm{D}_{3}\right)$ in vitro and in animal models of MS, which gained interest for this component in MS research the past decades (Smolders et al., 2016a). A poor circulating vitamin D status has been associated with a higher risk for developing MS and with an increased risk of higher disease activity in relapsing remitting MS (RRMS) (Ascherio et al., 2014; Munger et al., 2006). Since effects of vitamin $\mathrm{D}$ on $\mathrm{CD}^{+}{ }^{+} \mathrm{T}$ cell responses have been suggested as likely underlying mechanism (Smolders et al., 2008), several groups studied whether vitamin $\mathrm{D}_{3}$ supplements associate with $\mathrm{T}$ cell related cytokineprofiles in patients with MS. However, results reported are heterogeneous and poorly reproducible. This heterogeneity can be explained by small power of individual studies, but also different patients characteristics and different MS disease modifying treatments in patients. As laboratory approaches, investigators measured circulating cytokine levels ((Åivo et al., 2015; Mahon et al., 2003; Røsjø et al., 2015; Toghianifar et al., 2015), T cell cytokine production with iFACS after short stimulation with phorbol 12-myristate 13-acetate (PMA)/ionomycin (Muris et al., 2016; Smolders et al., 2010), T cell cytokine production with iFACS after pre-stimulation with anti-CD3/anti-CD28/ specific stimuli followed by PMA/ ionomycin (Mrad et al., 2017; O'Connel et al., 2017; Sotirchos et al., 2016), or cytokine production in supernatants by peripheral blood mononuclear cells (PBMC) stimulated with anti-CD3 with/without anti-CD28 or other stimuli (Mrad et al.,

\footnotetext{
* Corresponding author at: Central Diagnostic Laboratory, Maastricht University Medical Center, PO box 5800, 6202AZ, Maastricht, the Netherlands.

E-mail address: jan.damoiseaux@mumc.nl (J. Damoiseaux).
} 
2017; Muris et al., 2016; O'Connell et al., 2017). Therefore, as different laboratory approaches have been used in these studies, they also may contribute to the heterogeneity in outcomes.

The objective of our study is to determine to what extent different laboratory approaches to quantify cytokines contribute to heterogeneity in outcomes. We explored the correlation between iFACS performed directly ex-vivo or after $72 \mathrm{~h}$ pre-stimulation with anti-CD3, and cytokine levels excreted in supernatants of PBMC culture with anti-CD3 for several frequently studied T cell-related cytokines. Furthermore, we explored an effect of vitamin $\mathrm{D}_{3}$ supplements on cytokine-producing $\mathrm{T}$ cells and cytokine levels in culture supernatants.

\section{Materials and methods}

\subsection{Study design and procedure}

This study reports a single-center sub-study of a multi-center, randomized, double-blind, placebo-controlled study, which was conducted between October 2014 and November 2016 (ClinicalTrials.gov NCT02096133, EudraCT 2014-000728-97) (Rolf et al., 2018b). This study was approved by the local ethical research committee 'METC-Z', and written informed consent was obtained from all study participants. In short, participants were randomly allocated in a 1:1 ratio to the vitamin $D_{3}$ or placebo group. Participants in the vitamin $D_{3}$ group received $4000 \mathrm{IU} /$ day vitamin $\mathrm{D}_{3}$ drops (Vigantol Oil, Merck, Darmstadt, Germany), patients in the placebo group received matched placebo. The dose of $4000 \mathrm{IU} /$ day was chosen because this is considered the tolerable upper intake level of vitamin D according to the Dietary Reference Intakes developed by the Food and Nutrition Board and the Institute of Medicine. Moreover, we have shown that this dose induced 25(OH)D levels exceeding $100 \mathrm{nmol} / \mathrm{L}$ in most patients (Rolf et al., 2018b), which has been advocated by a recent ECTRIMS workgroup report to be beneficial for MS related outcomes (Amato et al., 2017). Randomization was performed by the pharmacy. Study personnel, participants and care providers were blinded to the study interventions. Study visits for serum sampling were performed at baseline and at approximately 16 weeks.

\subsection{Participants}

All participants were female patients with relapsing-remitting MS (RRMS), according to the McDonald criteria (Polman et al., 2011). Other inclusion criteria were age $>18$, and treatment with injectable or oral disease modifying drugs (DMD; interferon-beta, glatiramer acetate, dimethyl fumarate, teriflunomide or fingolimod) or no DMD treatment, and no DMD-changes 3 months prior to baseline visit. Also, participants had to be premenopausal with a perceptible menstrual cycle. Oral contraception was allowed. Exclusion criteria were all contraindications for vitamin $\mathrm{D}_{3}$ supplementation, relapse within 6 weeks prior to study initiation, use of systemic glucocorticoids within 8 weeks prior to study initiation, use of vitamin D supplements $>1000$ IU/day, current (treatment for) major depression, pregnancy and glucocorticoid treatment for relapses during the trial.

\subsection{Cell isolation and culture}

Peripheral blood samples were collected in sodium heparin at baseline and at approximately 16 weeks (BD Bioscience, Breda, the Netherlands). PBMC were directly isolated using a standard Ficolldensity gradient (Histopaque; Sigma Aldrich, Zwijndrecht, the Netherlands) and centrifugation. PBMC were frozen in liquid nitrogen for batch-wise analysis at the end of the study. Paired samples were analyzed in the same batch. After thawing cells were kept in culture medium (RPMI-1640 medium supplemented with $10 \%$ fetal calf serum, $2 \%$ penicillin-streptomycin, $1 \%$ sodium pyruvate, and $1 \%$ non-essential amino acids). The same culture medium was used for ex-vivo as well as
$72 \mathrm{~h}$ culture conditions. For the direct ex-vivo analysis, we activated cells $5 \mathrm{~h}$ in vitro with phorbol 12-myristate 13-acetate (PMA) (50 ng/ $\mathrm{mL}$, Sigma Aldrich) and ionomycin ( $1 \mu \mathrm{g} / \mathrm{mL}$, Sigma Aldrich). Monensin $(1.25 \mu \mathrm{g} / \mathrm{mL}$, BD Biosciences) was added at the start of the culture. For the prolonged stimulation, cells were cultured for 3 days in a U-bottom 96-wells plate and stimulated with soluble anti-CD3 $(2.0 \mathrm{pg} / \mathrm{mL}$, WT32 IgG2a monoclonal antibody, kindly provided by dr. W Tax, Nijmegen, The Netherlands (Tax et al., 1983)). This culture was followed by a restimulation under the same conditions as ex-vivo activation. All cell cultures were performed in a $37{ }^{\circ} \mathrm{C}$ incubator with a humidified atmosphere containing $95 \%$ air and $5 \% \mathrm{CO}_{2}$. Cells were intracellularly stained after fixation and permeabilization (Cytofix/ Cytoperm, BD Biosciences) with anti-IFN- $\gamma$-FITC, anti-CD3-horizon 450, anti-CD8APC-H7 (all BD Biosciences, Breda, the Netherlands), anti-GM-CSF-PE, anti-IL-10-APC and anti-IL-17A-PerCP-Cy5.5 (all Biolegend, Uithoorn, the Netherlands) and anti-TNF $\alpha-P E C y 7$ (eBioscience, Vienna, Austria). Flowcytometry was performed on a FACS Canto II flowcytometer (BD Biosciences) and data were analyzed with FACS Diva software version 6.1.2. (BD Biosciences). Cytokine expression was analyzed in $\mathrm{CD}^{+} \mathrm{CD}^{-} \mathrm{T}$ cells, because stimulation with PMA and ionomycin interferes with $\mathrm{CD} 4$ expression. Although $\mathrm{CD} 3^{+} \mathrm{CD} 8^{-} \mathrm{T}$ cells will also contain $\mathrm{TCR} \gamma \delta \mathrm{T}$ cells, the cells are enriched for $\mathrm{CD} 4^{+} \mathrm{T}$ cells (Smolders et al., 2010). In the supernatants of the 3 day prolonged stimulation cultures, concentrations of IL-4, IL-10, IL-17A, IFN- $\gamma$, TNF- $\alpha$ and GMCSF were measured in duplicates with an in-house developed and validated multiplex immunoassay (ISO9001:2008 certified, Laboratory of Translational Immunology, University Medical Center Utrecht, the Netherlands) based on Luminex technology (xMAP, Luminex, Austin, TX) (de Jager et al., 2005; Schipper et al., 2008). Data were analyzed using Bio-Plex Manager software, version 6.1.1 (Biorad laboratories, Hercules, CA). Plasma samples were stored at $-80^{\circ} \mathrm{C}$ in which $25(\mathrm{OH})$ D levels were measured at the end of the study using LC-MS/MS as described previously (van den Ouweland et al., 2014).

\subsection{Statistical analyses}

Descriptive statistics of continuous data are provided as medians with interquartile ranges (IQR, $25^{\text {th }}-75^{\text {th }}$ percentile), categorical data are presented as $n(\%)$. Comparisons of continuous variables between two unpaired groups were performed using Mann-Whitney $U$ tests and of multiple unpaired groups with the Friedman test. Within group comparisons were performed using Wilcoxon signed-rank tests for paired data. Correlations were explored by calculating Spearman correlation coefficients. To explore an effect of vitamin $\mathrm{D}_{3}$ supplements on cytokine outcomes, ratios of baseline $(\mathrm{T}=0)$ and end-of-study $(\mathrm{T}=1)$ proportions or supernatant concentrations were compared between treatment arms (Mann-Whitney $U$ test). Figures were constructed with GraphPad Prism version 7 (GraphPad Software Inc., La Jolla CA), statistical analyses were conducted with SPSS version 23.0 (IBM Corp., Armonk, NY). Since 6 different cytokines were assessed, a P-value $\leq$ $0.008(\mathrm{P} \leq \alpha / n=0.05 / 6)$ was considered significant.

\section{Results}

3.1. Polyclonal stimulation with anti-CD3 affects proportions of $C D 4^{+} T$ cell-enriched $C D 3^{+} C D 8^{-}$lymphocytes positive for individual cytokines to a different extent when compared to directly ex-vivo

Of $\mathrm{N}=27$ RRMS patients, two blood samples were acquired with an interval of approximately 16 weeks. First, we analyzed the effect of prestimulation with anti-CD3 on the proportions of $\mathrm{CD}^{+} \mathrm{CD}^{-} \mathrm{T}$ cells positive for IFN- $\gamma$, IL-4, IL-10, IL-17A, GM-CSF and TNF- $\alpha$ as measured with iFACS (Fig. 1A). For IFN- $\gamma$, IL-4, IL-10, IL-17A and GM-CSF, prestimulation with anti-CD3 resulted in increased proportions of $\mathrm{CD}^{+} \mathrm{CD} 8^{-} \mathrm{T}$ cells expressing the respective cytokines (Fig. 1B-E \& G). Proportions $\mathrm{CD}^{+}{ }^{+} \mathrm{CD} 8^{-} \mathrm{T}$ cells positive for TNF- $\alpha$ were not affected by 

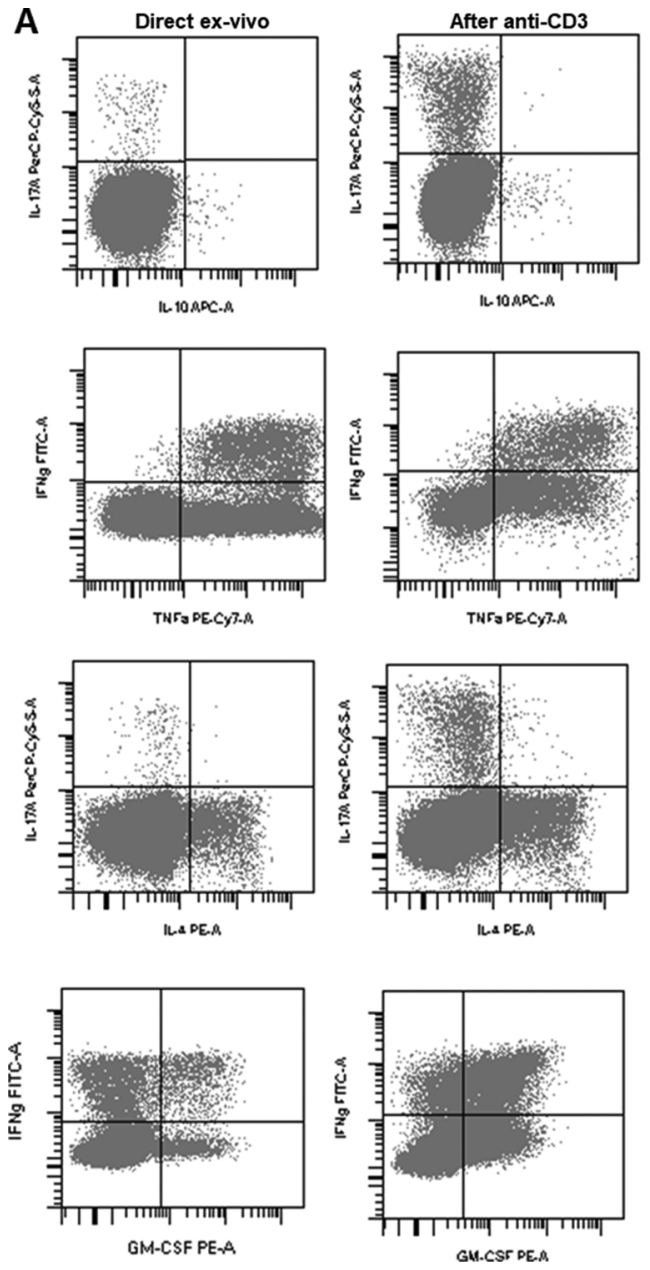

C
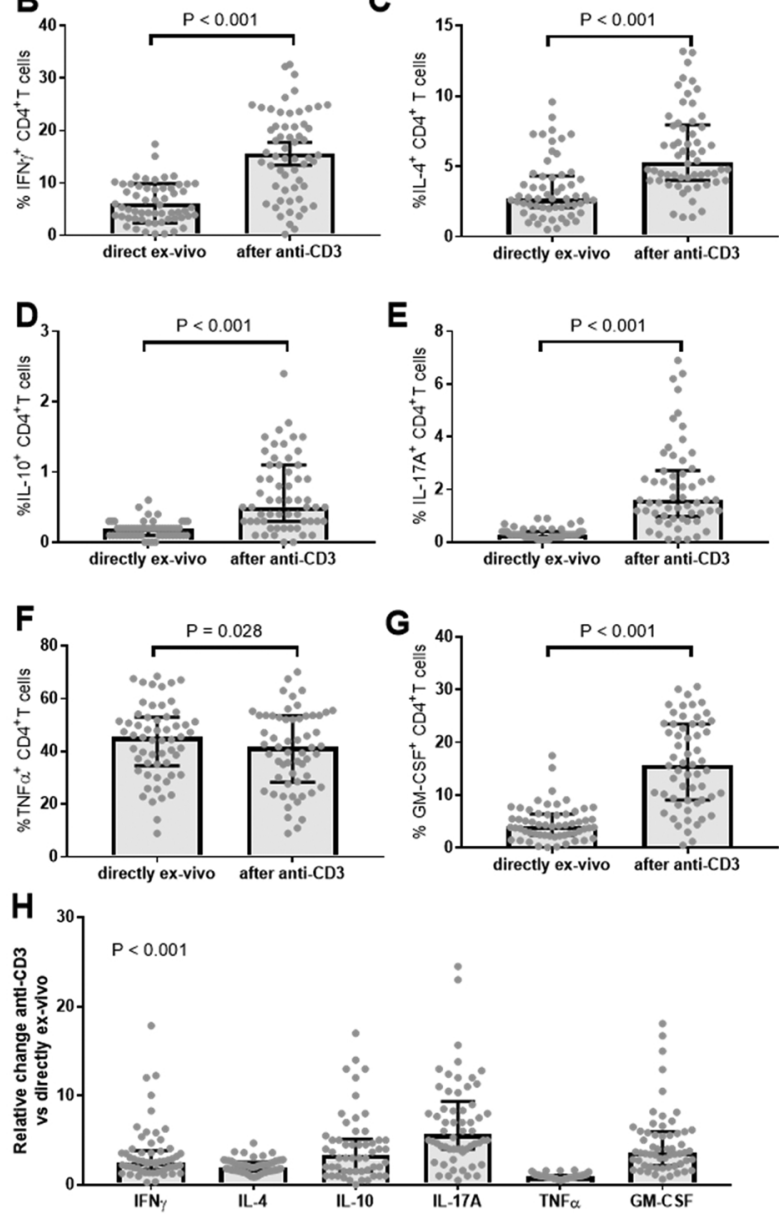

Fig. 1. Effect of pre-stimulation with anti-CD3 on the proportions of $\mathrm{CD} 3^{+} \mathrm{CD} 8^{-} \mathrm{T}$ cells expressing cytokines.

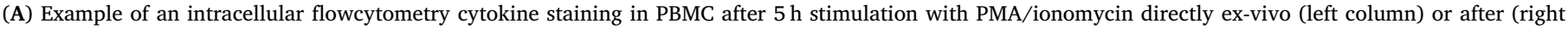

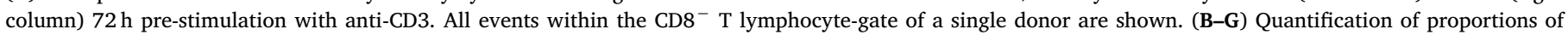

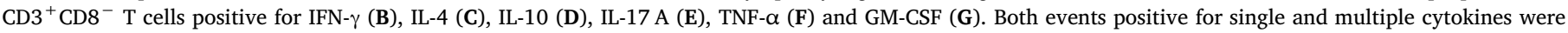

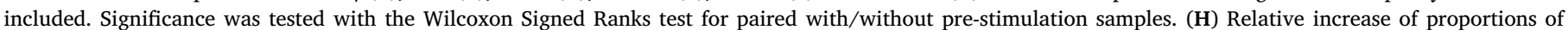
$\mathrm{CD}^{+} \mathrm{CD}^{-} \mathrm{T}$ cells positive for respective cytokines with compared to without pre-stimulation with anti-CD3. Significance was tested with the Friedman test.

stimulation with anti-CD3 (Fig. 1F). For all cytokines tested, the proportional differences between analysis-protocol with and without prestimulation with anti-CD3, differed from each other (Fig. $1 \mathrm{H}$, $\mathrm{P}<0.001$ ). There was an average 6.9-fold increase in cells positive for IL-17A, with only an average 2.1 to 3.4 -fold increase of IL- 4 and IFN- $\gamma$, respectively. The proportions of cells positive for IFN- $\gamma$, IL-4, IL-17A, GM-CSF and TNF- $\alpha$ as measured directly ex-vivo or after polyclonal stimulation showed a moderate to strong positive correlation (Fig. 2A,B,D-F), which was most pronounced for IL-4 and TNF- $\alpha$. There was no significant correlation between proportions positive for IL-10 (Fig. 2C).

3.2. Proportions of cells positive for individual cytokines show a variable correlation with concentrations in supernatants after polyclonal stimulation with anti-CD3

In the supernatants of the cultures pre-stimulated with anti-CD3, all cytokines could be measured with Luminex technology. There was a strong positive correlation between the proportions of IFN- $\gamma$ and IL-4 positive $\mathrm{CD} 3^{+} \mathrm{CD} 8^{-} \mathrm{T}$ cells and supernatant cytokine concentrations (Fig. 3A-B), and a moderate positive correlation for GM-CSF (Fig. 3F). The proportions of $\mathrm{CD}^{+}{ }^{+} \mathrm{CD} 8{ }^{-} \mathrm{T}$ cells positive for IL-10, IL-17 A and TNF- $\alpha$ did not correlate with the supernatant levels of these cytokines (Fig. 3C-E).

\subsection{Exploratory analyses do not reveal effects of vitamin $D_{3}$ supplements on cytokine outcomes}

We explored whether evolution of cytokine outcomes over 16 weeks differed between patients supplemented with vitamin $\mathrm{D}_{3}(\mathrm{~N}=12)$ or placebo-arm $(\mathrm{N}=15)$ (Table 1$)$. In the placebo group, the median 25(OH)D level at baseline was 78 (71-95) nmol/L, and 81 (61-90) $\mathrm{nmol} / \mathrm{L}$ at T1. In the vitamin $\mathrm{D}_{3}$ arm, this was 76 (71-132) nmol/L and 135 (123-144) nmol/L, respectively (difference between groups $\mathrm{P}=0.005)$. In the vitamin $\mathrm{D}_{3}$ group, $11 / 12$ had $25(\mathrm{OH}) \mathrm{D}$ levels exceeding $100 \mathrm{nmol} / \mathrm{L}$ at last visit, compared to $0 / 15$ in the placebogroup. For none of the outcomes reported on IFN- $\gamma$, IL-4, IL-10, IL-17A, TNF- $\alpha$, GM-CSF, there was a significant difference in absolute levels/ proportions or baseline vs 16-weeks ratios between vitamin $\mathrm{D}_{3}$ and placebo groups (Tables 2, S1-3). This is except for the levels of TNF- $\alpha$ observed in culture supernatants (Table S3), which were lower after 16 weeks follow-up in the vitamin $\mathrm{D}_{3}$ (1201.4 (782.6-2564.9) to 983 (540.1-1106.0) pg/mL, P = 0.008) but not the placebo-group (1147.8 (816.4-1625.0) to 1329.6 (850.6-2076.7) $\mathrm{pg} / \mathrm{mL}, \mathrm{P}=0.433)$.

\section{Discussion}

In this study, we compared three approaches to analyze cytokine production by $\mathrm{CD} 4 \mathrm{~T}$ cell-enriched $\mathrm{CD} 3^{+} \mathrm{CD} 8^{-}$lymphocytes in the 


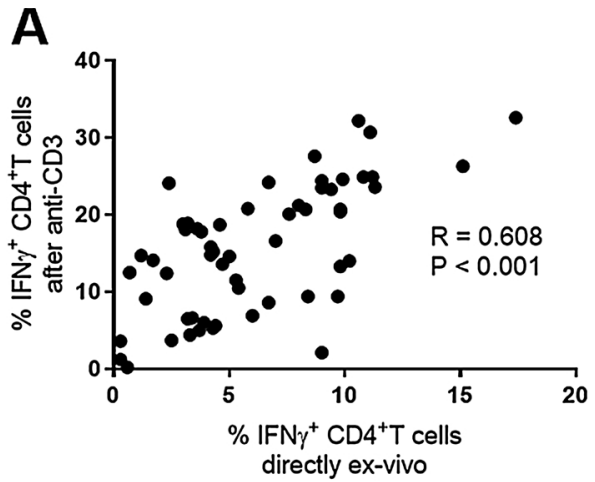

B
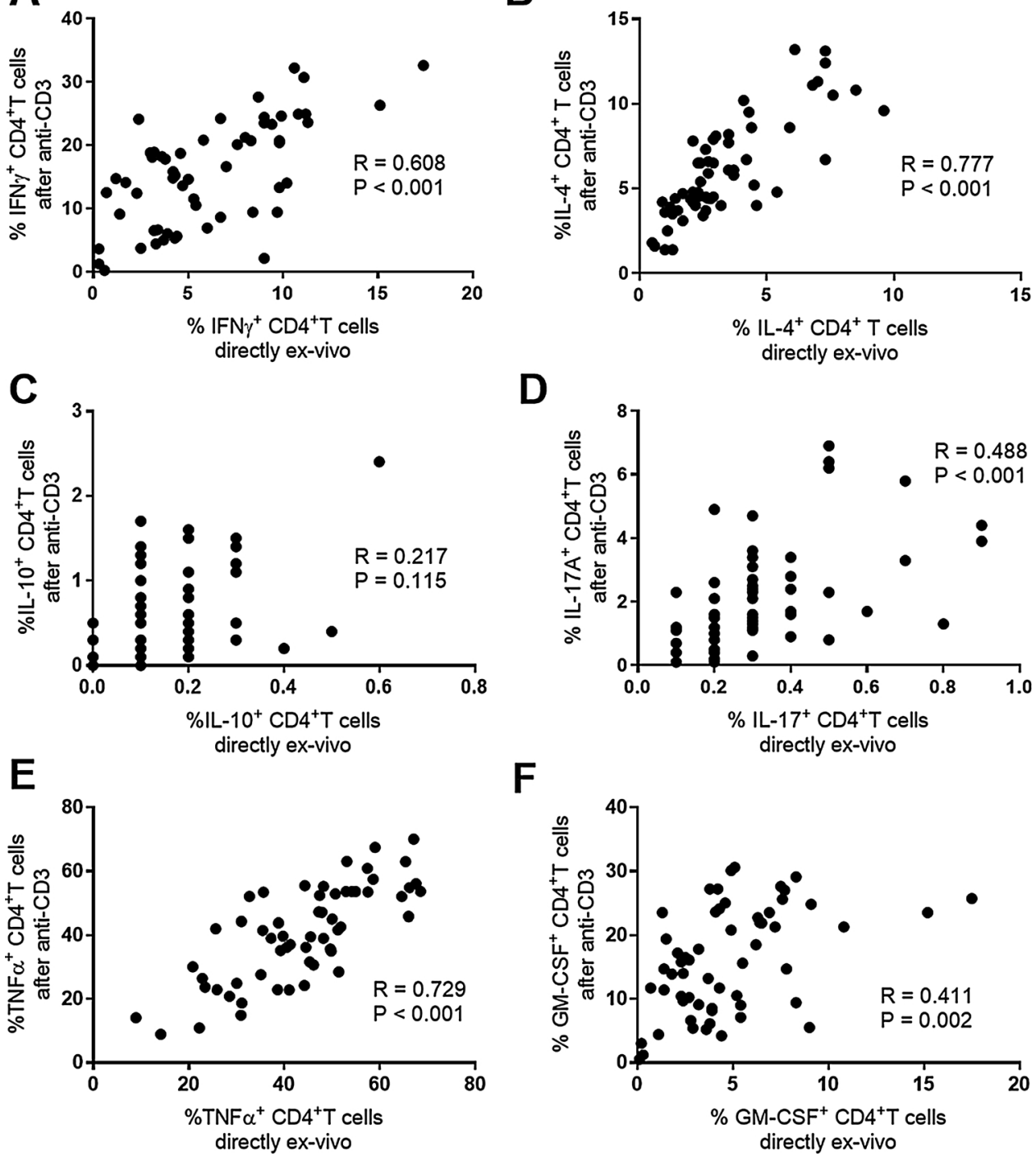

Fig. 2. Correlation between proportion of $\mathrm{CD} 3^{+} \mathrm{CD} 8^{-} \mathrm{T}$ cells expressing cytokines analyzed directly ex-vivo or after pre-stimulation with anti-CD3.



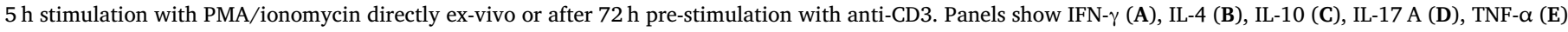
and GM-CSF (F). Spearman correlation coefficients with corresponding P-values are provided.

context of vitamin D supplementation in patients with MS. We observed that polyclonal stimulation of PBMC with anti-CD3 results in increased proportions of cells expressing several cytokines (IFN- $\gamma$, IL-4, IL-10, IL$17 \mathrm{~A}$ and GM-CSF) as measured with iFACS, but not all (TNF- $\alpha$ ). This increase is highly variable between individuals, and on average also different for distinct cytokines. There is a moderate to strong correlation between $\mathrm{CD}^{+} \mathrm{CD}^{-} \mathrm{T}$ cell proportions positive for individual cytokines directly ex-vivo or after $72 \mathrm{~h}$ pre-stimulation with anti-CD3, except for IL-10. The release of cytokines in supernatants after $72 \mathrm{~h}$ stimulation with anti-CD3 showed a moderate to strong positive correlation with the proportion of IFN- $\gamma$, IL-4 and GM-CSF-positive cells as measured with iFACS, but not with IL-10, IL-17A and TNF- $\alpha$. Therefore, especially in the case of small effects and sample sizes, the specific assay to analyze the $\mathrm{T}$ cell cytokine profile is likely to be a relevant confounder for the reproducibility of study results.

iFACS is a powerful technique to assess cell-specific cytokine profiles (Freer and Rindi, 2013), which has originally been designed and optimized for the analysis of IFN- $\gamma$, IL-2 and IL-4 (Jung et al., 1993) and later also IL-10 (Caraher, 2000). There are several parameters which must be taken care of during design and optimization of an experiment
(Lamoreaux et al., 2006). For our experiments, cells are stimulated with PMA/ ionomycin to boost cytokine production, which provides a strong $\mathrm{T}$ cell receptor independent stimulus. A caveat of intracellular cytokine analysis upon stimulation with PMA and ionomycin is the loss of CD4 expression. Therefore, $\mathrm{CD} 3^{+} \mathrm{CD} 8^{-} \mathrm{T}$ cells were analyzed although these are known to also include TCR $\gamma \delta$ T cells. Stimulation durations up to $6 \mathrm{~h}$ have been associated with increased proportions of IFN- $\gamma^{+} \mathrm{CD}^{+} \mathrm{T}$ cells (Caraher, 2000). Whether this is most optimal for the kinetics of all cytokines studied in our panel is uncertain. Release of cytokines is blocked by adding golgi-inhibitors brefeldin A or monensin, of which monensin is slightly more toxic to cells (Caraher, 2000). The use of golgi-inhibitors allows accumulation of cytokines in the cells. The timing of monensin addition to the cell culture is also a relevant variable, since longer addition to cultures associates with higher proportions of $\mathrm{CD}^{+} \mathrm{CD}^{-} \mathrm{T}$ cells positive for IFN- $\gamma$ and IL- 4 with higher MFIvalues (Muris et al., 2012). However, interfering with the golgi-apparatus is not beneficial for the detection of all cytokines. We showed earlier for IL-10 that monensin and brefeldin A reduce the proportions of $\mathrm{CD} 3^{+} \mathrm{CD} 8^{-} \mathrm{T}$ cells positive for IL-10 with almost $50 \%$ (Muris et al., 2012). Specific $\mathrm{IL}^{-} 4^{+} \mathrm{CD}^{+} \mathrm{T}$ cell responses against Chlamidia 

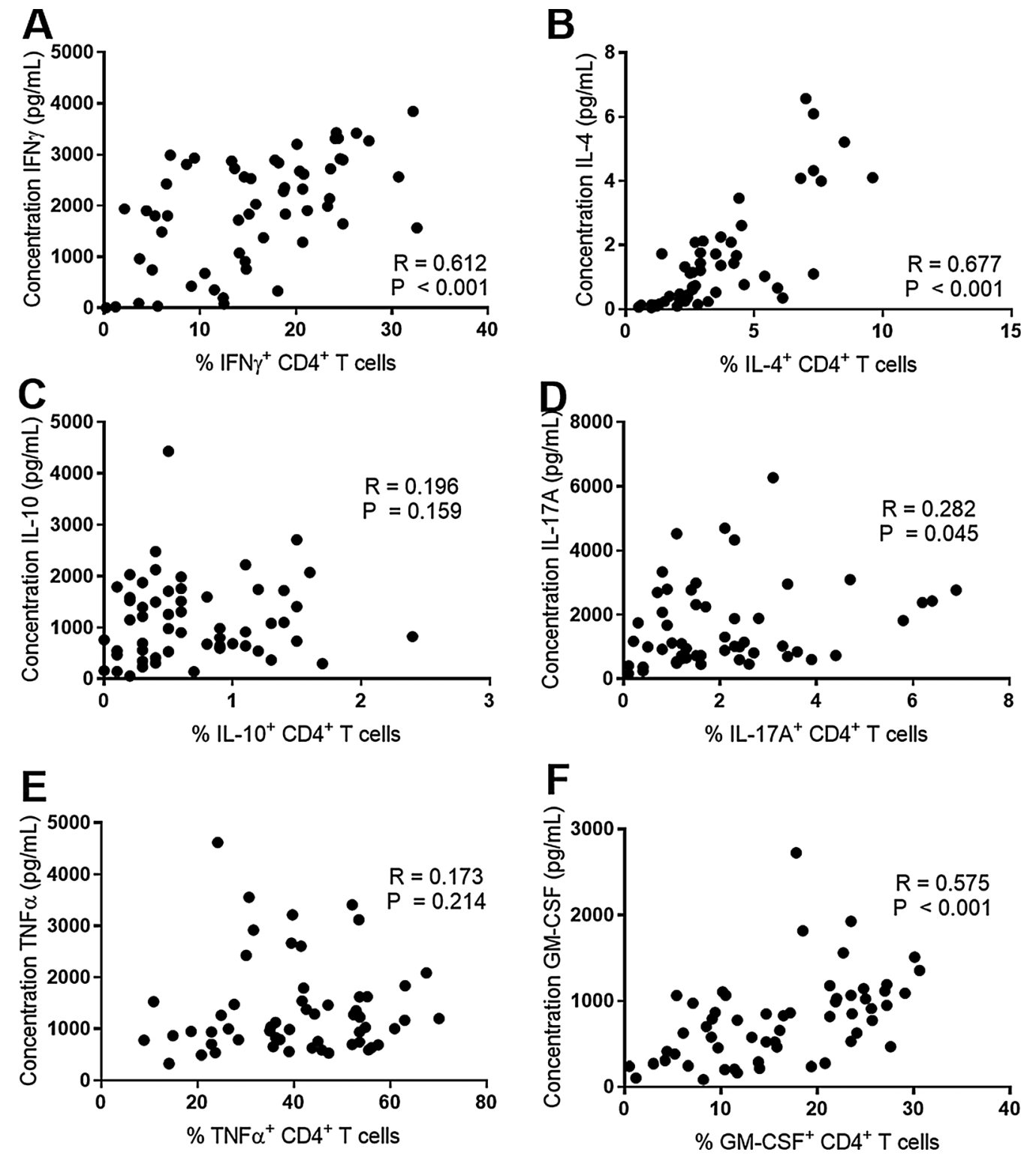

Fig. 3. Correlation between proportion of $\mathrm{CD} 3^{+} \mathrm{CD} 8^{-} \mathrm{T}$ cells positive for cytokines and cytokine levels in supernatants.

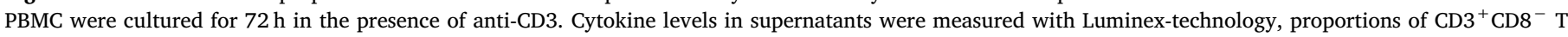

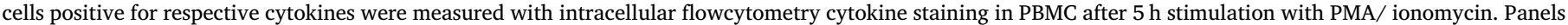
show IFN- $\gamma$ (A), IL-4 (B), IL-10 (C), IL-17 A (D), TNF- $\alpha$ (E) and GM-CSF (F). Spearman correlation coefficients with corresponding P-values are provided.

Trachomatis were specifically inhibited by brefeldin A and not monensin (Vicetti Miguel et al., 2012). Since the measurement of most cytokines clearly benefits from monensin, we did not omit this molecule from our iFACS protocol. We are, however, aware that by applying this protocol we measured IL-10 sub-optimally (Muris et al., 2012), and that this may contribute to the reported absence of a correlation between proportions $\mathrm{IL}_{10}{ }^{+} \mathrm{CD} 3^{+} \mathrm{CD}^{-} \mathrm{T}$ cells observed directly ex-vivo or after pre-stimulation with anti-CD3. For detection of intracellular cytokines with fluochrome-labeled antibodies, a fixation and permeabilization step is performed (Freer and Rindi, 2013). Our protocol allowed staining of 6 difference cytokines in 2 tubes. However, of several cytokines, very low proportions of positive cells were found. The more rare the events registered, the poorer the signal-noise ratio can be. This signal-noise ratio can also add to the poor correlation of study results, especially for the proportions of $\mathrm{IL}-10^{+}$and $\mathrm{IL}-17 \mathrm{~A}^{+} \mathrm{CD} 3^{+} \mathrm{CD} 8^{-} \mathrm{T}$ cells. Next, comparison of iFACS data obtained directly ex-vivo or after $72 \mathrm{~h}$ pre-stimulation with anti-CD3 may be hampered by several confounding factors, including potential short-term treatment effects in the cells analyzed directly ex-vivo, and/or a change in the pool of T cells upon culturing. Last, the cytokine levels measured in culture supernatants may also deviate from the results obtained by iFACS. First, culture supernatants were obtained after pre-stimulation with anti-CD3, but prior to re-stimulation with PMA and ionomycin. Second, the cytokine levels in culture supernatants are the result of production by all cells present in the culture system. In the case of anti-CD3 stimulated PBMC, these also comprise $\mathrm{CD}^{+} \mathrm{T}$ cells, but also, indirectly, B cells, NK-cells and myeloid cells will contribute to the cytokine levels. This also holds for cytokine-levels as measured in the patients circulation (Åivo et al., 2015; Mahon et al., 2003; Røsjø et al., 2015; Toghianifar et al., 2015). We did not perform these analysis in the current study, since concentrations of $\mathrm{T}$ cell cytokines in the circulation are low and usually fall within the bottom range of most assay's detection limits (personal experience).

To elaborate on the implications of our data, we discuss the example of IL-17. Although there are more cytokines to consider (Smolders et al., 2016b), IL-17 is an important CD4 ${ }^{+} \mathrm{T}$ cell inflammatory cytokine in the 
Table 1

Demographics.

\begin{tabular}{|c|c|c|}
\hline & Vitamin $\mathrm{D}_{3}(\mathrm{~N}=12)$ & Placebo $(\mathrm{N}=15)$ \\
\hline Age (years) & $39.7(26.7-44.6)$ & $35.1(33.0-45.0)$ \\
\hline \multicolumn{3}{|l|}{$\mathrm{BMI}(\mathrm{N})$} \\
\hline$\bullet<18.5$ & $2(16.7)$ & $0(0)$ \\
\hline - $18.5-25$ & $8(66.7)$ & $4(26.7)$ \\
\hline - $25-30$ & $1(8.3)$ & $7(46.7)$ \\
\hline - $>30$ & $1(8.3)$ & $4(26.7)$ \\
\hline \multicolumn{3}{|l|}{ Smoking (N) } \\
\hline - Never smoker & $6(50)$ & $11(73.3)$ \\
\hline - Former smoker & $2(16.7)$ & $3(20)$ \\
\hline - Current smoker & $4(33.3)$ & $1(6.7)$ \\
\hline Disease duration (years) & $3.1(2.0-10.0)$ & $5.4(1.8-6.8)$ \\
\hline \multicolumn{3}{|l|}{ Relapses in last year $(\mathrm{N})$} \\
\hline$\bullet 0$ & $10(83.3)$ & $12(80)$ \\
\hline - 1 & $1(8.3)$ & $3(20)$ \\
\hline - 2 & $1(8.3)$ & $0(0)$ \\
\hline Duration since last relapse (years) & $2.8(1.3-3.6)$ & $3.7(1.9-6.8)$ \\
\hline EDSS score (step 0-10) & $2.0(1.0-2.0)$ & $2.0(1.0-2.0)$ \\
\hline \multicolumn{3}{|l|}{ Treatment $(\mathrm{N})$} \\
\hline - No DMT & $2(16.7)$ & $1(6.7)$ \\
\hline - Interferon-bèta & $7(58.3)$ & $8(53.3)$ \\
\hline - Glatiramer acetate & $0(0)$ & $2(13.3)$ \\
\hline - Dimethylfumarate & $1(8.3)$ & $4(26.7)$ \\
\hline - Teriflunomide & $2(16.7)$ & $0(0)$ \\
\hline \multicolumn{3}{|l|}{ Vit D supplements $(\mathrm{N})^{\mathrm{a}}$} \\
\hline$\bullet<400 \mathrm{IU} /$ day & $4(33.3)$ & $1(6.7)$ \\
\hline - 400-800 IU/day & $0(0)$ & $2(13.3)$ \\
\hline - $800-1000 \mathrm{IU} /$ day & $7(58.3)$ & $10(66.7)$ \\
\hline - $1000 \mathrm{IU} /$ day & $1(8.3)$ & $2(13.3)$ \\
\hline Follow-up (weeks) & $16.1(16.0-16.9)$ & $15.9(15.0-16.4)$ \\
\hline
\end{tabular}

The median value (IQR) is shown for continuous variables, the number (percentage) is provided for categorical variables. BMI = body mass index; DMT = disease modifying treatment; EDSS = Expanded Disability Status Scale.

${ }^{a}$ Vit D doses indicated apply to vit D supplementation prior to entry of the study.

EAE animal model of MS, of which expression is directly modulated by vitamin D in EAE (Joshi et al., 2011). Sotirchos et al. (2016) showed a suppression of the proportion $\mathrm{IL}-17^{+} \mathrm{CD} 4^{+} \mathrm{T}$ cells measured after 5 days of in vitro stimulation with anti-CD3/CD28 in RRMS patients after 6 months supplementation of $12,000 \mathrm{IU} /$ day vitamin $\mathrm{D}_{3}$. Likewise, another controlled vitamin $\mathrm{D}_{3}$ supplementation study, using 50,000 IU/ day vitamin $\mathrm{D}_{3}$ every 5 days for 12 weeks, reported suppressed circulating IL-17 levels in MS (Toghianifar et al., 2015). Contrastingly, we did not observe any effect of either 48 weeks $14,000 \mathrm{IU} /$ day or 12 weeks $12,000 \mathrm{IU} /$ day on proportion of $\mathrm{CD} 3^{+} \mathrm{CD} 8^{-} \mathrm{IL}-17^{+} \mathrm{T}$ cells in RRMS as measured directly ex-vivo (Muris et al., 2016; Smolders et al., 2010). A similar finding was made in clinically isolated syndrome (CIS) patients who were supplemented with 5000 and 10,000 IU/day for 24 weeks, in which no increase in proportion IL- $17^{+} \mathrm{CD} 4{ }^{+} \mathrm{T}$ cells or IL-17 concentration in supernatants after 3 days polyclonal or 7 days antigenspecific stimulation was observed (O'Connell et al., 2017). In another study, circulating IL-17 levels were also not affected by 48 weeks vitamin $\mathrm{D}_{3}$ supplements (20,000 IU/week) (o et al., 2015). A study among MS patients with 25-hydroxyvitamin D levels $<\approx 62,5 \mathrm{nmol} / \mathrm{L}$ reported no effect of 3 months $10,000 \mathrm{IU} /$ day vitamin $\mathrm{D}_{3}$ on proportion $\mathrm{IL}^{-17^{+}} \mathrm{CD}^{+} \mathrm{T}$ cells or IL-17 release in supernatant after stimulation with anti-CD3/anti-CD28 (Mrad et al., 2017). Our data show that in addition to heterogeneity of patients included (amongst others use of distinct immunomodulatory therapy), supplementation protocols used, also the heterogeneity in laboratory techniques used contributes to variability in findings.

Although the sample size of our current RRMS cohort was small, we explored an effect of vitamin $\mathrm{D}_{3}$ supplements on our cytokine outcomes. There was no effect of vitamin D supplements on proportion of cytokine-producing $\mathrm{CD}^{+} \mathrm{CD}^{-} \mathrm{T}$ cells regardless of pre-stimulation with anti-CD3. These data are in line with earlier findings on IFN- $\gamma$, IL-4, IL10, IL-17A and GM-CSF (O'Connell et al., 2017; Mrad et al., 2017; Muris et al., 2016). Only the concentration of TNF- $\alpha$ decreased in supernatants of anti-CD3 stimulated PBMC cultures from our vitamin $\mathrm{D}_{3^{-}}$ treated individuals and not in the placebo group. This is in contrast with our findings from the SOLARIUM study, where an increase of excreted TNF- $\alpha$ in CD3-stimulated PBMC cultures was observed after 48 weeks follow-up regardless of vitamin $D_{3}$ supplements (Muris et al., 2016). Therefore, our current finding can be simply a chance finding, since our cohort is small and the difference just reached our pre-fixed significance level. Alternatively, the difference may be explained by different patients characteristics, or may reflect a temporal effect which is only visible at 16 and not 48 weeks follow-up. Interestingly, both in SOLARIUM and our current study, the proportions of $\mathrm{CD}^{+} \mathrm{CD}^{-} \mathrm{T}$ cells positive for TNF- $\alpha$ appear unaffected by vitamin $\mathrm{D}_{3}$ supplements (Muris et al., 2016). These proportions appear also to correlate poorly with the levels of TNF- $\alpha$ found in our anti-CD3 stimulated PBMC-culture supernatants. This raises the hypothesis whether monocytes or B-cells could be more relevant targets for vitamin $\mathrm{D}_{3}$ than $\mathrm{T}$ cells, as has been speculated earlier (Allen et al., 2012). However, in this regard we could not reveal a difference in TNF- $\alpha$ or IL-10 secretion in supernatants of LPS-stimulated PBMC, typically affecting monocytes via toll-like receptor 4 triggering, between patients supplemented with either vitamin $\mathrm{D}_{3}$ or placebo for 48 weeks (Rolf et al., 2017, [Rolf et al.,2018a]). When summarizing the findings of individual studies on vitamin $\mathrm{D}_{3}$ supplements and $\mathrm{T}$ cell related cytokine responses, the effects of supplements as can be quantified in peripheral blood or PBMC, if any, appears to be small and not generalizable to all cohorts. This overall negative finding is further supported by the functional genomics analysis of the BEST-D trial: the results of this study did not reveal any effect of vitamin $D_{3}$ supplementation on the whole-blood gene expression (Berlanga-Taylor et al., 2018). Obviously, the absence of a clear-cut effect of vitamin $D_{3}$ supplementation in humans is not in line with the consistent findings in vitro and in animal models, i.e., in combination with lymphocyte activation and antigen-specific read-outs (Damoiseaux and Smolders, 2018). Therefore, we recently speculated that assessment of more disease-specific cells and molecules in relevant (pre-morbid) patient cohorts may yield different results (Damoiseaux and Smolders, 2018). In

Table 2

Intracellular staining of $\mathrm{CD} 3^{+} \mathrm{CD} 8^{-} \mathrm{T}$ cells after $72 \mathrm{~h}$ stimulation with anti-CD3, followed by re-stimulation with PMA/ionomycin.

\begin{tabular}{|c|c|c|c|c|c|c|c|}
\hline & \multicolumn{3}{|l|}{ Vitamin $D_{3}$} & \multicolumn{3}{|l|}{ Placebo } & \multirow[b]{2}{*}{$\mathrm{P}^{* *}$} \\
\hline & T0 & $\mathrm{T} 1$ & $\mathrm{P}^{*}$ & T0 & $\mathrm{T} 1$ & $\mathrm{P}^{*}$ & \\
\hline IL-17A & $1.3(0.8-2.6)$ & $1.1(0.6-2.3)$ & 0.345 & $1.7(1.1-2.4)$ & $1.6(1.2-2.7)$ & 0.798 & 0.456 \\
\hline IL-10 & $0.4(0.1-1.1)$ & $0.4(0.2-0.6)$ & 0.364 & $0.5(0.4-1.0)$ & $0.6(0.3-1.1)$ & 0.706 & 0.443 \\
\hline IL-4 & $5.3(4.1-7.8)$ & $5.0(4.1-6.3)$ & 0.695 & $5.9(3.6-8.2)$ & $4.7(3.9-8.6)$ & 0.875 & 0.981 \\
\hline IFN- $\gamma$ & $17.1(10.2-24.0)$ & $13.8(6.6-20.6)$ & 0.136 & $15.8(10.5-23.6)$ & $15.1(9.1-20.1)$ & 0.394 & 0.236 \\
\hline TNF- $\alpha$ & $38.6(25.3-53.2)$ & $37.6(28.6-51.5)$ & 0.875 & $43.8(24.9-54.8)$ & $41.7(27.6-52.4)$ & 0.320 & 0.829 \\
\hline GM-CSF & $13.9(7.5-23.0)$ & $14.4(7.2-20.1)$ & 0.239 & $14.0(9.7-24.8)$ & $16.5(9.1-22.7)$ & 0.629 & 0.548 \\
\hline
\end{tabular}

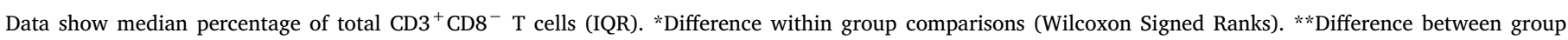
comparisons (Man Whitney U comparing T1/T0-ratios). 
line with this notion, a more MS-relevant immunological outcome to assess in association of vitamin $\mathrm{D}_{3}$ supplements may be circulating antiEpstein Barr virus nuclear antigen 1 (Ebna-1) immunoglobulin G (IgG) antibody levels. Also the Epstein-Barr virus (EBV) has been identified as an environmental risk factor for MS. In particular, higher anti-EBNA-1 IgG levels are associated with an increased risk of MS (Ascherio et al., 2001). A reduction of anti-Ebna-1 IgG has been reproducibly associated with 12-96 weeks vitamin $\mathrm{D}_{3}$ supplements in patients with MS (Disanto et al., 2013; Rolf et al., 2017, [Rolf et al.,2018a]; Røsjø et al., 2017), with one study reporting a rise in anti-Ebna-1 IgG over 6 months followup in $\mathrm{N}=13$ control and not in $\mathrm{N}=27$ vitamin $\mathrm{D}_{3}$-supplemented MS patients (Najafipoor et al., 2015).

In our study, we explored the correlations between several approaches to measure $\mathrm{CD} 3^{+} \mathrm{CD} 8^{-} \mathrm{T}$ cell cytokine responses in PBMC. Our analysis provides a best-case scenario: flowcytometry analyses were performed in a single-batch using the same reagents for stimulation and antigen-detection, all analyses were performed using the same flowcytometer. These are all factors which may introduce additional variation between studies. We conclude that experimental set-up introduces heterogeneity and may contribute to differences between studies in outcomes with a small effect size. Our data highlight that relatively small immunological studies in MS should be regarded as hypothesis generating. This paper is a call for research groups to perform reproducibility studies.

\section{Appendix A. Supplementary data}

Supplementary material related to this article can be found, in the online version, at doi:https://doi.org/10.1016/j.molimm.2018.12.001.

\section{References}

Åivo, J., et al., 2015. Vitamin D3 administration to MS patients leads to increased serum levels of latency activated peptide (LAP) of TGF-beta. J. Neuroimmunol. 28, 12-15.

Allen, A.C., et al., 2012. A pilot study of the immunological effects of high-dose vitamin D in healthy volunteers. Mult. Scler. 18, 1797-1800.

Amato, M.P., Derfuss, T., Hemmer, B., Liblau, R., Montalban, X., Soelberg Sorensen, P., et al., 2017. Environmental modifiable risk factors for multiple sclerosis: report from the 2016 ECTRIMS focused workshop. Mult. Scler. https://doi.org/10.1177/ 1352458516686847.

Ascherio, A., Munger, K.L., Lennette, E.T., Spiegelman, D., Hernan, M.A., Olek, M.J., et al., 2001. Epstein-Barr virus antibodies and risk of multiple sclerosis: a prospective study. JAMA 286, 3083-3088.

Ascherio, A., et al., 2014. Vitamin D as an early predictor of multiple sclerosis activity and progression. JAMA Neurol. 71, 306-314.

Becher, B., Spath, S., Goverman, J., 2017. Cytokine networks in neuroinflammation. Nat. Rev. Immunol. 17, 49-59.

Beebe, A.E., Orr, M.T., 2017. Assessment of antigen-specific cellular immunogenicity using intracellular cytokine staining, ELISpot, and culture supernatants. Methods Moll. Biol. 1494, 313-320.

Berlanga-Taylor, et al., 2018. Genomic response to vitamin D supplementation in the setting of a randomized, placebo-controlled trial. EBioMedicine. https://doi.org/10. 1016/j.ebiom.2018.04.010.

Caraher, E.M., 2000. Flow cytometric analysis of intracellular IFN-gamma, IL-4 and IL-10 in CD3(+)4(+) T-cells from rat spleen. J. Immunol. Methods 244, 29.

Carter, L.L., Swain, S.L., 1997. Single cell analyses of cytokine production. Curr. Opin. Immunol. 9, 177.

Damoiseaux, J., Smolders, J., 2018. The engagement between vitamin D and the immune system: is consolidation by a marriage to be expected? EBioMedicine 31, 9-10. https://doi.org/10.1016/j.ebiom.2018.04.013.

de Jager, W., et al., 2005. Improved multiplex immunoassay performance in human plasma and synovial fluid following removal of interfering heterophilic antibodies. J.
Immunol. Methods 300 (1-2), 124-135.

Disanto, G., et al., 2013. Vitamin D supplementation and antibodies against the EpsteinBarr virus in multiple sclerosis patients. Mult. Scler. 19, 1679-1680.

Freer, G., Rindi, L., 2013. Intracellular cytokine detection by fluorescence-activated flow cytometry: basic principles and recent advances. Methods 61 (1), 30-38.

Joshi, S., et al., 2011. 1,25-dihydroxyvitamin D(3) ameliorates Th17 autoimmunity via transcriptional modulation of interleukin-17A. Mol. Cell. Biol. 31, 3653-3669.

Jung, T., et al., 1993. Detection of intracellular cytokines by flow cytometry. J. Immunol. Methods 159 (1-2), 197-207.

Lamoreaux, L., Roederer, M., Koup, R., 2006. Intracellular cytokine optimization and standard operating procedure. Nat. Protoc. 1, 1507-1516.

Mahon, B.D., et al., 2003. Cytokine profile in patients with multiple sclerosis following vitamin D supplementation. J. Neuroimmunol. 134, 128-132.

Mrad, M.F., et al., 2017. Effect of vitamin D replacement on immunological biomarkers in patients with multiple sclerosis. Clin. Immunol. 181, 9-15.

Munger, K., et al., 2006. Serum 25-hydroxyvitamin D levels and risk of multiple sclerosis. JAMA 296, 2832-2838.

Muris, A.H., et al., 2012. Intracellular IL-10 detection by flowcytometry: the use of protein transport inhibitors revisited. J. Immunol. Methods 381, 59-65.

Muris, A.H., et al., 2016. Immune regulatory effects of high dose vitamin D3 supplementation in a randomized controlled trial in relapsing remitting multiple sclerosis patients receiving IFN $\beta$; the SOLARIUM study. J. Neuroimmunol. 300, 47-56.

Najafipoor, A., et al., 2015. The beneficial effects of vitamin D3 on reducing antibody titers against Epstein-Barr virus in multiple sclerosis patients. Cell. Immunol. 294, $9-12$.

O'Connell, K., et al., 2017. Effects of vitamin D3 in clinically isolated syndrome and healthy control participants: A double-blind randomised controlled trial. Mult. Scler. J. Exp. Transl. Clin. 32055217317727296.

Polman, C.H., et al., 2011. Diagnostic criteria for multiple sclerosis: 2010 revisions to the McDonald criteria. Ann. Neurol. 69, 292-302.

Røsjø, E., et al., 2015. Vitamin D supplementation and systemic inflammation in relapsing-remitting multiple sclerosis. J. Neurol. 262, 2713-2721.

Røsjø, E., et al., 2017. Effect of high-dose vitamin $\mathrm{D}_{3}$ supplementation on antibody responses against Epstein-Barr virus in relapsing-remitting multiple sclerosis. Mult. Scler. 23, 395-402

Rolf, L., et al., 2017. Vitamin $\mathrm{D}_{3}$ supplementation in multiple sclerosis: symptoms and biomarkers of depression. J. Neurol. Sci. 378, 30-35.

Rolf, L., et al., 2018a. Exploring the effect of vitamin $\mathrm{D}_{3}$ suplementation on the anti-EBV antibody response in relapsing remitting multiple sclerosis. Mult. Scler. 24, 1280-1287. https://doi.org/10.1177/1352458517722646.

Rolf, L., et al., 2018b. Stress-axis regulation by vitamin $\mathrm{D}_{3}$ in multiple sclerosis. Front. Neurol. 9, 263

Schipper, H.S., et al., 2008. A multiplex immunoassay for human adipokine profiling. Clin. Chem. 56 (8), 1320-1328.

Smolders, J., et al., 2008. Vitamin D as an immune modulator in multiple sclerosis, a review. J. Neuroimmunol. 194 (1-2), 7-17.

Smolders, J., et al., 2010. Safety and T cell modulating effects of high dose vitamin $\mathrm{D}_{3}$ supplementation in multiple sclerosis. PLoS One 5, e15235.

Smolders, J., Hupperts, R., Damoiseaux, J., 2016a. Shining light on vitamin D and multiple sclerosis. In: Arnon, R. (Ed.), Translational Neuroimmunology of Multiple Sclerosis: From Disease Mechanisms to Clinical Applications. Elsevier, London (UK), pp. 369-387 chapter 25.

Smolders, J., Muris, A.H., Damoiseaux, J., 2016b. Immunomodulation by vitamin D in multiple sclerosis: more than IL-17. J. Neuroimmunol. 292, 79-80.

Sotirchos, E.S., et al., 2016. Safety and immunologic effects of high- vs low-dose cholecalciferol in multiple sclerosis. Neurology 86, 382-390.

Tax, W.J., et al., 1983. Polymorphism in mitogenic effect of IgG1 monoclonal antibodies against T3 antigen on human T cells. Nature 304, 445-447.

Toghianifar, N., et al., 2015. Effect of high dose vitamin D intake on IL-17 levels in multiple sclerosis: a randomized, doubleblind, placebo-controlled clinical trial. J. Neuroimmunol. 285, 125-128.

Van den Ouweland, J.M., Beijers, A.M., van Daal, H., 2014. Overestimation of 25-hydroxyvitamin D3 by increased ionisation efficiency of 3-epi-25-hydroxyvitamin D3 in LC-MS/MS methods not separating both metabolites as determined by an LC-MS/MS method for separate quantification of 25-hydroxyvitamin D3, 3-epi-25-hydroxyvitamin D3 and 25-hydroxyvitamin D2 in human serum. J. Chromatogr. B Analyt. Technol. Biomed. Life Sci. 967, 195-202.

Vicetti Miguel, R.D., et al., 2012. Brefeldin A, but not monensin, enables flow cytometric detection of interleukin-4 within peripheral $\mathrm{T}$ cells responding to ex vivo stimulation with Chlamydia trachomatis. J. Immunol. Methods 384 (1-2), 191-195. 